\title{
Girassol (Helianthus annuus L.) e seus coprodutos na alimentação animal
}

\author{
Rayanne Viana Costa ${ }^{1}$, Joelson Antonio Silva ${ }^{2}$, Rosemary Lais Galati ${ }^{3}$, Camilla Gabriela \\ Miranda Silva ${ }^{2}$, Moacir Ferreira Duarte Júnior ${ }^{2}$ \\ ${ }^{1}$ Graduação em Zootecnia, FAMEV/UFMT, Cuiabá-MT \\ ${ }^{2}$ Programa de Pós-Graduação em Ciência Animal, FAMEV/UFMT, Cuiabá-MT \\ ${ }^{3}$ Professor adjunto, DEZER/FAMEV/UFMT, Cuiabá-MT \\ *Autor para correspondência, E-mail: joelson.silva@hotmail.com
}

\begin{abstract}
RESUMO. A utilização de coprodutos das agroindústrias na alimentação animal já é realizada á muitos anos. Com o incentivo a produção nacional de Biodisel a geração desses subprodutos teve significativo aumento, possibilitando sua utilização na alimentação animal, pelo aumento da oferta de farelos ou tortas oriundos da extração do óleo de oleaginosas. O farelo de soja é a principal fonte protéica utilizada na alimentação de animais ruminantes e monogástricos, todavia com o aumento da demanda mundial por alimentos de alto valor proteico, não competitivos com a alimentação humana, impulsiona a utilização destes coprodutos na alimentação animal, principalmente para ruminantes, pela sua capacidade singular de transformação de fibras não digestíveis pelo organismo humano, em produtos de alto valor biológico, como carne e leite. Dentre as culturas utilizadas na produção de Biodiesel, o girassol teve expressivo aumento na produção e produtividade nos últimos anos, graças a sua capacidade de adaptação a diversas condições edafoclimáticas. Os coprodutos do girassol possuem características nutricionais favoráveis para alimentação dos animais de interesse zootécnico, minimizando os custos de produção e maximizando a produção de carne e leite.
\end{abstract}

Palavras-chave: Biodiesel, coprodutos, girassol, farelo de soja

\section{Sunflower (Helianthus annuus $L$.) and their coproduct in animal feed}

\begin{abstract}
The use of co-products of agro-industries in animal feed has already been done for many years. With the encouragement of domestic production of Biodiesel generation of these products had increased significantly, allowing its use in animal feed, by increasing the supply of meals or pies from the extraction of oil from oilseeds. Soybean meal is the main source of protein fed to ruminants and monogastric animals, but with increasing global demand for food high in protein, not competitive with human food, boosts the use of these co-products in animal feed, mainly for ruminants, due to its unique ability to transform non-digestible fibers by the human body, products of high biological value such as meat and milk. Among the crops used to produce Biodiesel, sunflower had a significant increase in production and productivity in recent years, thanks to its adaptability to various soil and climatic conditions. The co-products of sunflower have favorable nutritional characteristics of feed animals of zootechnical interest, minimizing production costs and maximizing production of meat and milk.
\end{abstract}

Keywords: Biodiesel, co-products, sunflower, soybean meal

\section{Introdução}

A alimentação animal com coprodutos de agroindústrias tem sido realizada há muitos anos. Essa prática apresenta diversas vantagens, como a possibilidade de utilização de alimentos não empregados na alimentação humana, a agregação de valor a produtos que provavelmente seriam descartados pela agroindústria e, além disso, a destinação apropriada aos mesmos, contribuindo para diminuição dos riscos de poluição ambiental provocada pelo seu acúmulo. Dessa forma, a utilização de coprodutos da agroindústria na alimentação animal apresenta relevância do ponto de vista nutricional, econômico e ambiental, possibilitando um desenvolvimento sustentável, ambientalmente correto, socialmente justo e 
economicamente viável (Santos, 2008).

De acordo com Santos et al. (2008) o milho e a soja são os principais ingredientes utilizados nas rações dos animais de produção. Devido ao grande crescimento da população mundial e a exigência cada vez maior por alimentos de alto valor protéico, não competitivos com a alimentação humana, surge à necessidade de utilização de alimentos alternativos na alimentação animal.

A expectativa de crescimento gradual da participação do Biodiesel na matriz energética mundial criou oportunidades para a produção, principalmente de ruminantes através da oferta potencial de farelos ou tortas obtidos após a extração do óleo de sementes de oleaginosas, constituindo os principais coprodutos da cadeia produtiva do Biodiesel. Desta forma, permite-se integrar as cadeias de agroenergia e pecuária, otimizando a geração de emprego e renda e minimizando os passivos ambientais. Neste sentido, estudos que permitem gerar informações sobre a melhor forma de utilização dos coprodutos na alimentação de ruminantes fazemse necessários, para garantir a sustentabilidade desta integração (Oliveira, 2008).

Para Oliveira et al. (2010) a viabilização econômica e ambiental do uso do Biodiesel em substituição gradual ao diesel de petróleo dependente, dentre outros fatores, do aproveitamento ótimo dos coprodutos gerados na cadeia produtiva. Os principais coprodutos são obtidos após a extração do óleo de sementes oleaginosas (tortas e farelos) e após o processo de conversão do óleo em Biodiesel por meio de transesterificação (glicerina bruta), os quais, em conjunto, representam mais de $50 \%$ da massa inicial de sementes utilizada na cadeia agroindustrial.

O Brasil possui predominantemente clima tropical, com pequena área localizada no sul caracterizada como subtropical possibilitando uma ampla variedade de matérias-primas para a produção de biodiesel, gerando a dúvida de qual oleaginosa a ser industrializada. Existem várias opções, com destaque para soja, algodão, palma (dendê), girassol, nabo forrageiro, canola, mamona, e pinhão manso. Dentre estes, o girassol é uma cultura que se potencializa cada vez mais como uma solução de plantio na entressafra das culturas de milho, soja e algodão, possuindo diversos cultivares que se adaptam por todo o território brasileiro (Nogueira Júnior,
2006).

Segundo Companhia Nacional de Abastecimento (CONAB, 2014) a região CentroOeste ocupa lugar de destaque na produção nacional de girassol com 227 mil toneladas produzidas na safra 2013/2014, representando 91,9\% da produção nacional. A produção do país teve um expressivo aumento, impulsionado pelo incentivo a produção de oleaginosas utilizadas na obtenção de Biodiesel, sendo um crescimento na safra de 2013/2014 de 375\% em relação à safra de 2002/2003.

Desta forma, este estudo tem como objetivo revisar a importância da substituição da principal fonte protéica utilizada na nutrição animal, destacando os efeitos de sua substituição pelos coprodutos da cultura do girassol, bem como atender a exigência de avaliação da disciplina de Análise de Alimentos para obtenção do título de Mestre em Ciência Animal.

\section{Mercado de alimentos protéicos utilizados na alimentação animal}

Pinto \& Fontana (2001) comentam que o milho e a soja são os principais ingredientes das rações para vacas leiteiras. Nas propriedades brasileiras que trabalham com animais especializados em produção de leite, o farelo de soja tem sido utilizado como ingrediente prevalecente na composição dos concentrados. Contudo, o aumento no custo de produção e a implementação de soja transgênica sem regulamentação clara, tornaram o farelo de soja uma fonte protéica onerosa e muito discutida. Além disso, o grande crescimento da população mundial e a exigência cada vez maior por alimentos de alto valor protéico, não competitivos com a alimentação humana, impulsionam a utilização de coprodutos na nutrição animal.

Os farelos e tortas de oleaginosas representam a principal fonte de proteína utilizada em rações para animais de interesse zootécnico no Mundo. Segundo levantamento da Sociedade Americana de Soja, o farelo de soja representou 69\% do consumo mundial de farelos protéicos no ano de 2008, seguido pelo farelo de canola (12\%), algodão (7\%) e girassol (4\%) (Oliveira et al., 2010).

Dentre os alimentos protéicos utilizados em rações comerciais para animais de interesse zootécnico no Brasil, o farelo de soja se destaca, com $66,1 \%$ de participação, seguido pela farinha 
de carne/ossos e óleo com $23 \%$ e farelo de algodão com 5\% (Tabela 1).

Goes et al. (2010) afirmam que o milho e o farelo de soja são os dois principais alimentos utilizados na formulação de rações, para ruminantes. Isso porque ambos não apresentam nenhuma restrição quanto à presença de fatores anti nutricionais e, juntos, formam excelente combinação de energia e proteína. A elevação do custo destes alimentos aumentou o custo de produção, com isso, torna-se necessário avaliar as possibilidades de utilização de alimentos alternativos de boa qualidade, que possuam menor custo, permitindo assim, manter o patamar atual de produção de rebanhos.

A disponibilidade, preços competitivos e valor nutricional são os principais fatores que influenciam a demanda por alimentos protéicos em rações para animais. Espera-se que com o crescimento da oferta de outras oleaginosas destinadas á produção de biodiesel (canola, crambe, girassol, macaúba, mamona, palma, pinhão-manso, dentre outras) reduza a dependência do farelo de soja em rações para animais, o que contribuirá para reduzir a competição com a alimentação humana e aumentar as opções para os produtores (Oliveira et al., 2010).

Tabela 1. Participação na demanda total de macro nutriente protéicos em rações comerciais para cada categoria animal no Brasil (mil toneladas)

\begin{tabular}{|c|c|c|c|c|c|c|c|}
\hline & \multicolumn{2}{|c|}{ Avicultura } & \multirow{2}{*}{ Suinocultura } & \multicolumn{2}{|c|}{ Bovinocultura } & \multirow{2}{*}{ Outros } & \multirow{2}{*}{$\begin{array}{l}\text { Total } \\
\text { Geral } \\
\end{array}$} \\
\hline & Corte & Postura & & Corte & Leite & & \\
\hline Farelo de soja & $7.485,7$ & 942,6 & $2.425,8$ & 168,5 & 554,9 & 313,9 & $12.408,0$ \\
\hline Farinha de carne/ossos e óleo & $2.814,7$ & 231,9 & 922,3 & 0,0 & 0,0 & 231,7 & $4.379,6$ \\
\hline Farelo de algodão (40\% PB) & 0,0 & 0,0 & 0,0 & 470,4 & 477,8 & 33,7 & 982,0 \\
\hline Farelo de glúten de milho (21\% PB) & 81,6 & 1,1 & 0,0 & 114,1 & 263,0 & 158,2 & 618,1 \\
\hline Farelo de glúten de milho (60\% PB) & 151,3 & 1,3 & 0,0 & 0,1 & 0,7 & 32,6 & 185,9 \\
\hline Ureia e Enxofre & 0,0 & 0,0 & 0,0 & 47,9 & 0,0 & 0,0 & 195,9 \\
\hline Demanda total & $30.259,6$ & $31.770,0$ & $15.330,0$ & $2.519,0$ & $4.630,6$ & $3.828,0$ & $63.547,8$ \\
\hline
\end{tabular}

Fonte: Adaptado de Sindirações (2010).

\section{Fatores que afetam o valor nutritivo dos produtos da extração do óleo de sementes}

O valor nutritivo dos coprodutos da extração de óleo de sementes de oleaginosas depende basicamente do método de extração, do grau de decorticação da semente, do processamento do produto e da espécie de oleaginosa (Oliveira, 2008).

Em revisão realizada pelo mesmo autor, foi encontrado na semente de girassol 35 a $45 \%$ de extrato etéreo e 25 a $30 \%$ de casca, sendo o teor de proteína bruta dos coprodutos protéicos obtido após a extração do óleo de 28 a $50 \%$, com base na matéria seca. A casca da semente de girassol contém baixo teor de PB (5\%, base na MS), altos teores de fibra em detergente neutro $(73 \%$, base da MS) e de lignina (26\%, base da MS). O autor ainda afirma que o grau de decorticação apresenta-se como principal fator de variação no valor nutritivo de farelos ou tortas de girassol.

\section{Processo de extração do óleo}

Segundo Hayward (1993) e Gallup et al. (1950), a extração do óleo de girassol é realizada por processo mecânico e químico. A extração pelo processo mecânico é realizada por prensas hidráulicas, consistindo no processo industrial pioneiro utilizado na extração do óleo de girassol. Em razão de sua baixa eficiência de extração foram gradualmente substituídas por prensas tipo Expeller, desenvolvida no final da década de 90, as quais constituem atualmente no processo majoritário de extração mecânica de óleo (Oliveira et al., 2010).

Denomina-se de torta o produto resultante da extração mecânica e farelo resultante da extração química. A torta obtida de extração por prensa hidráulica apresenta maior teor de óleo e, conseqüentemente, menor teor de proteína em relação aquela resultante da extração por prensa tipo expeller, além de maior variabilidade. $\mathrm{O}$ farelo, por ser obtido de um processo mais eficiente na extração do óleo, contém menor teor de extrato etéreo e, consequentemente, maior teor de proteína bruta (Oliveira et al., 2010).

O processo mecânico de extração é menos eficiente. A torta de girassol é um dos produtos resultantes desta extração, possui pouco mais de $20 \%$ de proteína bruta e aproximadamente $15 \%$ 
de óleo, com base na matéria seca (Oliveira \& Lew, 2002). É o método mais popular para eliminar o óleo das sementes oleaginosas. As prensas mecânicas do tipo expeller são amplamente utilizadas nos países em desenvolvimento, apresentando uma série de vantagens perante o tradicional método de extração por solvente. A operação em uma prensa mecânica é simples, não exigindo mão-de-obra qualificada para seu manuseio; é um sistema facilmente adaptável a diversos tipos de oleaginosas, bastando para isso alguns simples ajustes mecânicos, e todo o processo de expulsão do óleo é contínuo e feito em um curto espaço de tempo (Singh \& Bargale, 2000).

De acordo com Oliveira et al. (2010) a extração do óleo, por meio da prensagem mecânica, para a produção do biocombustível é uma opção econômica para pequenos produtores, resultando em um ingrediente pronto para ser utilizado diretamente na propriedade. Neste caso, o processo de extração mecânico é realizado por uma miniprensa, através somente de esmagamento do grão sem aquecimento e o teor de óleo na torta de girassol varia em função da regulagem da miniprensa.

Oliveira \& Vieira (2004) comentam que uma das principais características do girassol, quando comparado a outras oleaginosas, é a facilidade do seu processamento. As sementes de girassol são processadas inteiras e a temperatura ambiente (dispensando cozimento prévio). Isso é possível devido à rotação relativamente alta, aliada ao teor de cascas da semente, o que produz atrito, aquecendo o grão dentro da máquina, facilitando a extração do óleo. Nas miniprensas, usa-se uma rosca sem fim que esmaga as sementes numa velocidade lenta. O fluxograma do processo de extração do óleo encontra-se na Figura 1.

A compra da miniprensa para o esmagamento do girassol e produção da torta na propriedade é viável economicamente devido à receita obtida com a venda do óleo, o que viabiliza a sua aquisição e proporciona maior rendimento líquido em relação ao farelo e à torta comprada (SOUSA, 2008). A formação de cooperativas ou associações possibilita sua compra por pequenos produtores, diversificando a fonte de renda com a venda do óleo. O coproduto desse processamento, no caso a torta, pode ser utilizado na alimentação animal, reduzindo o custo de produção e diminuindo o passivo ambiental.

Segundo Rossi (1998), os azeites e óleos vegetais são gorduras líquidas provenientes de frutos e sementes. Os azeites são obtidos por pressão, como é o caso da utilização de miniprensas. Os óleos são obtidos por pressão, solventes e posterior purificação e refinação. $\mathrm{Na}$ prática, o azeite é o óleo vegetal que não é extraído por solventes químicos e não sofre processo de refinação (Oliveira \& Vieira, 2004).

No processo químico, envolve além da prensagem, a utilização de hexano como solvente e caracteriza-se pela elevada eficiência, que maximiza a extração de óleo das sementes, resultando no farelo de girassol, produto com cerca de $1,5 \%$ de óleo na matéria seca e níveis de proteína que podem variar de 28 até $42 \%$ (Cati, 2001).

Para Carvalho (2006) o girassol está entre as quatro maiores culturas oleaginosas produtoras de óleo vegetal comestível no mundo, representando $9,0 \%$ do total de óleos elaborados mundialmente em volume, ocupando o quarto lugar em volume de produção, perdendo posição apenas para o óleo de soja, palma e colza.

Devido ao alto teor de óleo, na semente, é possível efetuar sua extração a frio, sem condicionamento térmico prévio. O óleo de girassol apresenta baixo teor de gorduras saturadas (cerca de 10\%), aproximando-se do milho quanto ao teor de gorduras monoinsaturadas (24\%), sendo o que possui maior teor de gorduras poliinsaturadas (66\%) (Tabela 2), sendo esse teor constituído quase totalmente pelo ácido linoléico, o qual, embora essencial ao desempenho das funções fisiológicas importantes no organismo humano, não é sintetizado pelo mesmo (Nogueira Junior, 2006; Oliveira \& Vieira, 2004). No processo de esmagamento, dependendo da variedade utilizada, o percentual de óleo obtido oscila entre 38 a 48\% (Carvalho, 2006).

Gazzoni (2005) salienta que o girassol pode ser cultivado antecipando-se à cultura principal, como alternativa ao milho. Com o planejamento adequado, o grão pode ser estocado e transformado em combustível, de acordo com as demandas energéticas ao longo do ano. 


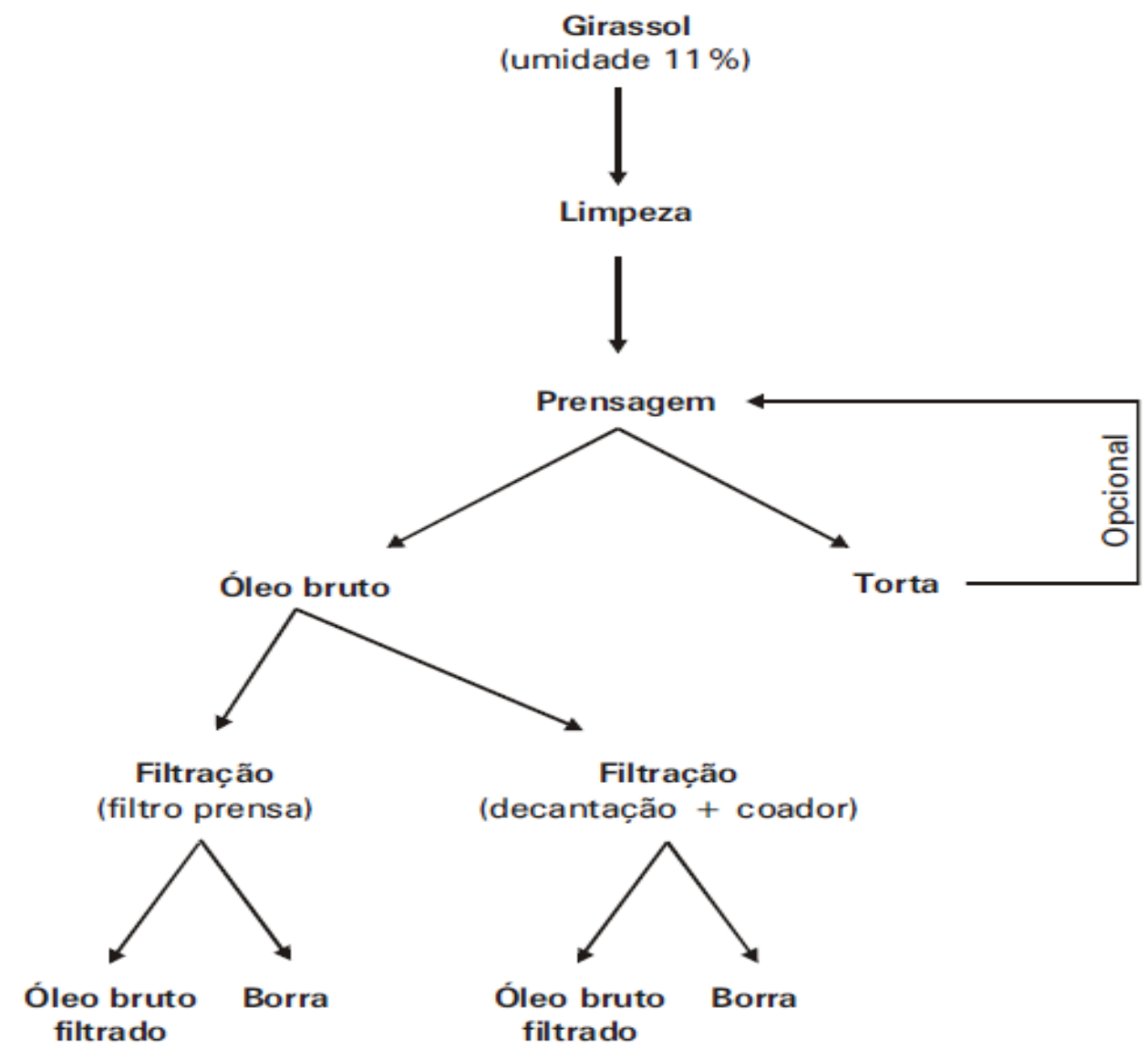

Figura 1. Fluxograma do processamento do girassol em miniprensa

Tabela 2. Teor médio de ácidos graxos (\%) presentes nos diferentes vegetais

\begin{tabular}{lcccccc}
\hline \multirow{2}{*}{ Oleaginosas } & \multicolumn{3}{c}{$\begin{array}{c}\text { Principais ácidos graxos } \\
\text { componentes }\end{array}$} & $\begin{array}{c}\text { Ácidos graxos } \\
\text { saturados }\end{array}$ & \multicolumn{2}{c}{ Ácidos graxos insaturados (\%) } \\
\cline { 2 - 7 } & C18:1 & C18:2 & C18:3 & $(\%)$ & Monoinsaturados & Poliinsaturado \\
\hline Algodão & 13,7 & 56,5 & 0,1 & 26,8 & 14,4 & 20,0 \\
Amendoin & 40,7 & 33,9 & 0,1 & 21,3 & 17,1 & 34,0 \\
Canola & 60,3 & 20,1 & 9,5 & 6,3 & 62,8 & 29,6 \\
Girassol & 23,1 & 65,1 & 0,2 & 11,6 & 23,1 & 65,3 \\
Linhaça & 19,9 & 15,9 & 52,7 & 9,5 & 19,9 & 68,6 \\
Palma & 17,1 & 2,9 & 0,1 & 76,5 & 17,1 & 3,0 \\
Soja & 24,8 & 52,4 & 7,7 & 15,2 & 24,8 & 60,0 \\
\hline
\end{tabular}

Oléico (C18:1); Linoléico (C18:2); Linolênico (C18:3). Fonte: Adaptado de Oliveira e Vieira (2004).

Por outro lado, é importante destacar que o óleo de girassol é considerado nobre e muito valorizado no mercado, devido ao elevado teor de ácidos graxos poliinsaturados, com elevado teor nutricional, podendo encarecer a matéria-prima para obtenção de energia. Porém, mesmo que o óleo de girassol não seja destinado integralmente ou em sua maior proporção ao uso energético, ele contribuirá para aumentar a oferta quantitativa global de óleos comestíveis do país.

\section{Grau de decorticação}

Segundo Arija et al. (1998) e Oliveira (2008) o grau de decorticação (retirada da casca) da semente representa o principal fator que modula o valor nutricional de tortas e farelos de oleaginosas. Cascas de sementes da maioria das oleaginosas (algodão, girassol, mamona, pinhãomanso) apresentam baixos. Este comportamento decorre da elevada presença de lignina e cutina 
(Oliveira et al., 2010).

É importante destacar que ocorre grande variação na composição química da torta de girassol (Tabela 3) devido, principalmente, pela realização do procedimento de decorticação do grão de girassol.

Tabela 3. Composição da torta de girassol, sob diferentes tratamentos

\begin{tabular}{lccccccc}
\hline \multirow{2}{*}{ Torta de girassol } & ES & EE & PB & PDR & FDN & FDA & Lig \\
\cline { 2 - 8 } & 92,4 & 6,75 & 25,9 & - & 41,0 & 27,0 & 8,4 \\
\hline Não decorticada & - & 31,4 & 28,1 & 92 & 25,3 & 17,6 & 8,7 \\
Decorticada & & & Nutrientes & $(\% M S)$ \\
\hline
\end{tabular}

Nutrientes ${ }^{1}$ : Matéria Seca (MS); extrato etéreo (EE); proteína bruta (PB); proteína degradável no rúmen (PDR); fibra em detergente neutro (FDN); fibra em detergente ácido (FDA) e lignina (Lig).

Fontes: Adaptado de Santos (2008).

A lignina representa o principal componente que afeta a digestibilidade da fração potencialmente digestível da FDN. Além de ser indigestível, por formar ligações tipos ésteres com a hemicelulose, as quais não são hidrolisadas por enzimas microbianas, reduz à extensão e a velocidade da degradação ruminal da FDN, implicando em menor consumo de FDN digestível (Oliveira et al., 2010).

\section{Cultura do girassol}

A cultura do girassol foi introduzida no Brasil no período da colonização, nunca ocupou lugar de destaque na economia nacional, já que sempre foi vista como de pouca expressão econômica. Os cultivares eram suscetíveis a algumas doenças, apresentavam baixas produtividades, baixo teor de óleo, problemas de comercialização além do pouco conhecimento, por parte dos agricultores, quanto às tecnologias de produção (Carvalho, 2006).

Segundo estimativas da Conab (2014) a área cultivada com girassol no ano agrícola de 2013/2014 foram de 144,3 mil hectares e uma produção de 247,4 mil toneladas no mesmo período, um aumento de $104,7 \%$ e $124,5 \%$ em relação ao ano agrícola de 2012/2013, respectivamente. Mostrando que o girassol se consolidou como cultura de expressão no Brasil, graças ao melhoramento genético realizado pelas instituições de pesquisa e ao aumento da demanda por oleaginosas para produção de Biodiesel.

De acordo com Mcguffey \& Schingoethe (1982), o girassol (Helianthus annus L.) é uma espécie dicotiledônea anual da família Compositae (ou Asteraceae), sendo originária do continente norte-americano. Apresenta caule ereto, geralmente não ramificado, com altura variando entre 1,0 e $2,5 \mathrm{~m}$ e com cerca de 20 a 40 folhas por planta. Sua flor é chamada de capítulo, onde se desenvolvem os grãos, denominados de aquênios, constituídos pelo pericarpo (casca) e pela semente propriamente dita (amêndoa). Variam conforme o tamanho, cor e teor de óleo (35-45\%) dependendo do cultivar (Sousa, 2008).

Seu nome derivado do grego hélios, que significa sol e anthus que significa flor, ou seja, é a flor do sol. Na Tabela 4, podemos visualizar as características da planta como altura, tamanho do capítulo, tamanho do aquênio, variam consideravelmente de acordo com o genótipo da planta Correia (2009).

De acordo com a utilização, há dois tipos de sementes de girassol: as oleosas e as não-oleosas. As sementes não-oleosas são maiores, pretas, com listras e apresentam casca (pericarpo) facilmente removível que constitui $40-45 \%$ do peso da semente, têm de $25-30 \%$ de óleo e representam somente $5 \%$ dos genótipos de girassol (Vieira, 2005 citado por Correia, 2009). As sementes oleosas são menores, com pericarpo bem aderido, representando $20-30 \%$ do peso das sementes. São economicamente mais importantes, e a partir delas, são produzidos farelo de girassol e seus derivados, após a extração do óleo (Correia, 2009).

Tabela 4 - Amplitude de variação de característica da planta de girassol.

\begin{tabular}{lc}
\hline Característica & Amplitude de variação \\
\hline Altura da planta $(\mathrm{cm})$ & $50-400$ \\
Diâmetro do caule $(\mathrm{mm})$ & $15-90$ \\
Diâmetro do capítulo $(\mathrm{mm})$ & $6-50$ \\
Óleo no aquênio $(\%)$ & $10-60$ \\
Óleo na amêndoa $(\%)$ & $26-72$ \\
\hline
\end{tabular}

Fonte: Correia (2009). 
Carvalho (2006) comenta que suas raízes são do tipo pivotante, promovem grande reciclagem de nutrientes, exploram grandes volumes e buscam nutrientes em camadas não alcançadas por raízes de outras culturas. Portanto, aproveita muito bem a adubação residual da cultura anterior, além de proporcionar considerável quantidade de matéria orgânica deixada no solo ao final do ciclo. Devido à maior eficiência na absorção de água e maior tolerância a baixas temperaturas, o girassol é indicado como segunda cultura proporcionando aumento de produtividades nas culturas posteriores. Estima-se que estes aumentos são de 15 a $20 \%$ para o milho e 10 a $15 \%$ para soja.

Segundo Bremner et al. (1986) o girassol é caracterizado por apresentar maior resistência ao frio e ao calor que a maioria das culturas, além de apresentar ampla adaptabilidade às diferentes condições edafoclimáticas. Sua capacidade de extrair água disponível na camada de zero a dois metros de profundidade foi estimada em aproximadamente $92 \%$, contra $64 \%$ do sorgo (Evangelista \& Lima, 2001). Tais características tornam a cultura do girassol uma alternativa ao milho no período da safrinha (Pinto \& Fontana, 2001), sendo opção de rotação e sucessão de culturas nas regiões produtoras de grãos. Como a safra inicia-se em fevereiro e termina em agosto, abrange justamente a entressafra do milho e sorgo, além de coincidir com o período de escassez de forragem. Numa época em que a terra normalmente fica ociosa, o girassol torna-se boa alternativa para reforçar a dieta do rebanho (Santos, 2008).

As sementes do girassol são do tipo aquênio, constituído pelo pericarpo (casca) e pela semente propriamente dita (amêndoas), de tamanho, cor e teor de óleo variável (30 a 48\% de óleo) dependendo do cultivar e o número mais freqüente de aquênios pode oscilar de 800 a 1.700 , por capítulo. Seu caule é robusto, ereto, provido ou não de pêlos e geralmente sem ramificações, e as folhas são alternadas, pecioladas com grande variação de número $(8$ a 70), forma e tamanho (Evangelista \& Lima, 2001).

Apesar de o óleo ser o principal produto do girassol, o farelo e a torta, derivados com valor comercial, podem ser utilizados na alimentação humana ou animal; suas raízes promovem considerável reciclagem de nutrientes, além de matéria orgânica após colheita; as hastes servem para silagem e para adubação verde, além de serem utilizadas como material de forro acústico; sua associação com a apicultura permite a produção de 20 a $40 \mathrm{~kg}$ de mel por hectare de cultura (Fagundes, 2002).

Tabela 5. Composição bromatológica em \% da matéria seca, da torta e do farelo de girassol

\begin{tabular}{lcc}
\hline \multicolumn{1}{c}{ Itens } & Torta de girassol & Farelo de girassol \\
\hline Matéria seca & 91,90 & 90,92 \\
Proteína bruta & 22,90 & 31,37 \\
Extrato etéreo & 15,53 & 1,08 \\
Fibra em & 38,33 & 46,54 \\
detergente neutro & & \\
Fibra em & 29,32 & 37,29 \\
detergente ácido & 8,10 & 4,67 \\
Matéria mineral &
\end{tabular}

Fonte: Sousa (2008).

$\mathrm{Na}$ nutrição de ruminantes, tanto o farelo quanto a torta de girassol tornam-se alternativas de alimento, por possuírem altos teores de proteína e energia. Porém, as informações disponíveis quanto à composição nutricional destes coprodutos apresentam grandes variações em função dos diferentes processos de extração do óleo. Na Tabela 5 podemos observar as diferenças entre o farelo e torta de girassol Sousa (2008).

\section{Silagem de girassol}

Na maioria das regiões do Brasil, a produção bovina está sujeita às variações na disponibilidade e na qualidade de alimentos ao longo do ano. Por isso, a conservação de forragens torna-se alternativa viável para suplementação alimentar do rebanho no período de menor disponibilidade de alimentos (inverno), uma vez que a maior produção de matéria seca ocorre durante os meses de alta pluviosidade (verão). Dentre as práticas de conservação de forragens, destaca-se a ensilagem, que permite a utilização mais eficiente da terra e possibilita a produção de alimentos volumosos de elevado valor nutricional.

A silagem de milho é considerada padrão, e seu valor nutritivo é tomado como referência, mas o alto valor comercial do milho grão, que é utilizado na alimentação humana e de animais não ruminantes, obriga a busca por novas alternativas (Ko et al., 2005). De acordo com Resende \& Evangelista (2004), as culturas de milho e sorgo têm sido as mais utilizadas devido, principalmente, à facilidade de cultivo e aos altos rendimentos de matéria seca e de carboidratos solúveis. 
Como já afirmado por Carvalho (2006) o girassol apresenta boa adaptabilidade as diferentes condições edafoclimáticas, devido ao seu sistema radicular ser do tipo pivotante o que lhe possibilita extrair água, nutrientes e sais minerais, disponível nas camadas mais profundas do solo, não alcançadas por raízes de outras culturas. É uma opção de rotação e sucessão de culturas nas regiões produtoras de grãos. Como a safra inicia-se em fevereiro e termina em agosto, abrange justamente a entressafra do milho e sorgo, além de coincidir com o período de escassez de forragem (Santos, 2008).

Assim, o uso do girassol na alimentação animal sob a forma de silagem tem surgido como boa alternativa para o Brasil devido aos períodos de déficit hídrico, que impossibilitam a produção de alimentos volumosos de boa qualidade e, consequentemente, a manutenção da produção animal durante todo o ano. O cultivo do girassol (Helianthus annuus L.), após a retirada da cultura de verão, pode ser uma opção para maximizar a produção de volumoso, servindo para o preparo de silagem de boa qualidade ou mesmo para produção de forragem verde. Entretanto, pouco se conhece sobre o seu potencial forrageiro e o valor nutritivo de sua silagem (Evangelista \& Lima, 2001). Avaliando o potencial forrageiro de 13 variedades de girassol Tomich et al. (2003) encontraram produção variando de 12,8 a 29,1 toneladas por hectare de massa verde (Tabela 6). Destaque foi observado para o híbrido Contiflor 3 quando se considera rendimento forrageiro associado a maior proporção de capítulos em relação ao caule e folha, este híbrido teve produção de matéria seca de 6,8 toneladas/hectare.

$\mathrm{O}$ teor de matéria seca tem importância fundamental sobre a qualidade da silagem. Entretanto, recomendações para ensilagem em dias após o plantio ou emergência, como ocorre com o milho ou o sorgo, não se aplicam ao girassol, uma vez que o teor de matéria seca da planta é variável conforme o estádio de desenvolvimento da cultura, do cultivar e das condições de cultivo (Evangelista \& Lima, 2001). Em média, quando a colheita do girassol é realizada com $90 \%$ dos grãos maduros, os diferentes cultivares de girassol têm resultado em silagens cujo teor de matéria seca gira em torno de 25\% (Jayme, 2003).

Em revisão realizada por Jayme (2003) foi observado uma variação muito grande a respeito do ponto ideal de ensilagem do girassol, com recomendações da época ideal de colheita do girassol durante toda a floração, final da floração co capítulo já maduros, no estágio farináceo e quando a planta se apresenta com a cor pardacenta. Para Pereira et al. (1999), o momento ideal de colheita do girassol para ensilar á na maturidade fisiológica das plantas, quando parte vegetativa está completamente madura, as brácteas estão amarelas a castanhas e as folhas murchas ou secas.

Tabela 6. Produção de matéria verde e de matéria seca de cultivares de girassol

\begin{tabular}{lcc}
\hline Híbrido ou & \multicolumn{2}{c}{ Produção (toneladas/ha) } \\
\cline { 2 - 3 } variedade & Matéria verde & Matéria seca \\
\hline AS243 & $26,3^{\mathrm{AB}}$ & $7,0^{\mathrm{AB}}$ \\
AS603 & $23,9^{\mathrm{ABC}}$ & $5,8^{\mathrm{ABC}}$ \\
Cargill 11 & $12,8^{\mathrm{E}}$ & $4,7^{\mathrm{CD}}$ \\
Contiflor 3 & $26,4^{\mathrm{AB}}$ & $6,8^{\mathrm{ABC}}$ \\
Contiflor 7 & $15,6^{\mathrm{DE}}$ & $6,0^{\mathrm{ABC}}$ \\
DK180 & $19,2^{\mathrm{BCDE}}$ & $5,3^{\mathrm{BCD}}$ \\
M734 & $22,1^{\mathrm{ABCD}}$ & $6,4^{\mathrm{ABC}}$ \\
M737 & $29,1^{\mathrm{A}}$ & $6,7^{\mathrm{ABC}}$ \\
M738 & $17,9^{\mathrm{CDE}}$ & $5,6 \mathrm{~A}^{\mathrm{BC}}$ \\
M742 & $24,7^{\mathrm{ABC}}$ & $6,5 \mathrm{~A}^{\mathrm{BC}}$ \\
Rumbosol 90 & $15,9^{\mathrm{DE}}$ & $5,2^{\mathrm{BCD}}$ \\
Rumbosol 91 & $29,1^{\mathrm{A}}$ & $7,7^{\mathrm{A}}$ \\
V2000 & $12,8^{\mathrm{E}}$ & $3,6^{\mathrm{D}}$ \\
Média & $21,2^{\mathrm{B}}$ & 5,9 \\
CV (\%) & $16,8^{\mathrm{B}}$ & 16,8 \\
\hline
\end{tabular}

Médias seguidas por letra distintas na coluna diferem $(\mathrm{P}<0,05)$ entre si pelo teste SNK;

Fonte: Tomich et al. (2003).

Com relação ao seu teor de carboidratos solúveis na matéria original, possui $3,06 \%$, ideal para que não ocorra fermentação clostridiana na massa ensilada, todavia apresenta um alto poder tampão, com resistência para promover o rápido abaixamento do $\mathrm{pH}$ da massa ensilada (Evangelista \& Lima, 2001).

Mizubuti et al. (2002) avaliando a composição química das silagens de milho, sorgo e girassol, observaram teor de matéria seca nas silagens de 29,$56 ; 24,94$ e 18,83\%, respectivamente. De acordo com os autores este baixo teor de matéria seca é devido a silagem ter sido confecionada com a planta no início da maturação fisiológica dos grãos. Não houve diferença para o teor de proteína e FDA para as silagens de milho e girassol. Não foi observado diferença significativa para os coeficientes de 
digestibilidade da FDN e PB das silagens de milho, sorgo e girassol, foi observado difenças para os coeficientes de digestibilidade aparente para a MS, FDA e PB (Tabela 7).

Avaliando o coeficiente de digestibilidade da matéria seca das silagens de três cultivares de girassol Resende e Evangelista (2004) observaram sua diminuição a medida que a ensilagem foi realizada com plantas em estádios mais avançados de maturação, sendo as médias dos coeficientes de digestibilidade da matéria seca de 62, 37; 56,12 e 49,44\% para 95, 110 e 125 dias de idade, respectivamente. Os autores acreditam que, provavelmente, essa redução esteja relacionada à maior interferência da fração lipídica em função de maior volume de grãos e ao aumento no conteúdo de lignina no caule, os quais poderiam estar inibindo a digestibilidade da matéria seca.

Tabela 7. Coeficientes de digstibilidade aparente (CDA) da matéria seca (MS), fibra em detergente ácido (FDA), fibra em detergente neutro (FDN), extrato etéreo (EE) e proteína bruta (PB) das diferentes silagens e balanço de nitrogênio nos animais

\begin{tabular}{lcccccc}
\hline \multirow{2}{*}{ Silagens } & \multicolumn{5}{c}{ Coeficientes de digestibilidade (\%) } & \multirow{2}{*}{ Balanço de nitrogênio (g/dia) } \\
\cline { 2 - 5 } & MS & FDA & FDN & EE & PB & \\
\hline Milho & $55,87^{\mathrm{AB}}$ & $64,45^{\mathrm{A}}$ & $50,89^{\mathrm{A}}$ & $82,57^{\mathrm{B}}$ & $59,92^{\mathrm{A}}$ & $5,38^{\mathrm{A}}$ \\
Sorgo & $48,50^{\mathrm{B}}$ & $48,61^{\mathrm{B}}$ & $46,37^{\mathrm{A}}$ & $64,70^{\mathrm{C}}$ & $53,52^{\mathrm{A}}$ & $2,53^{\mathrm{B}}$ \\
Girassol & $59,28^{\mathrm{A}}$ & $52,88^{\mathrm{B}}$ & $51,92^{\mathrm{A}}$ & $92,07^{\mathrm{A}}$ & $57,03^{\mathrm{A}}$ & $5,32^{\mathrm{A}}$ \\
CV (\%) & 12,54 & 13,69 & 12,29 & 5,52 & 14,00 & 17,71 \\
\hline
\end{tabular}

Médias seguidas de letras diferentes na coluna diferem $(\mathrm{P}<0,05)$ pelo teste Turkey.

Fonte: Mizubuti et al. (2002).

Ribeiro et al. (2002) ao estudarem dietas a base de silagem de milho, sorgo e girassol, no desempenho de ovelhas adultas da raça Hampshire Down, observaram ganho de peso diário de $34 \%$ superior, em média, para as ovelhas que receberam silagem de girassol do que para as ovelhas que receberam as outras silagens. De acordo com os autores, outros fatores ligados à composição e digestibilidade da silagem de girassol devem ter influído no maior ganho de peso nas ovelhas. Mizubuti et al. (2000) verificaram maior consumo de extrato etéreo $(9,55 \mathrm{~g} / \mathrm{kg} 0,75 / \mathrm{dia})$ em ovinos alimentados exclusivamente com silagem de girassol, bem como uma maior digestibilidade aparente $(92 \%)$ desta fração, do que em animais alimentados com silagem de milho (3,69 g/kg0,75/dia e 82,5\%).

Leite et al. (2006) avaliaram o consumo e a digestibilidade aparente de dietas contendo diferentes proporções de silagem de girassol em substituição à silagem de milho, para vacas leiteiras em lactação, observaram redução $(3,7 \%)$ do consumo de matéria seca quando houve substituição total da silagem de milho pela silagem de girassol, porém, não foi observada diferença entre os tratamentos utilizados, em relação ao consumo de proteína bruta, apesar das diferenças no consumo de matéria seca.
Quanto aos constituintes da parede celular, a lignina, em termos percentuais da fibra em detergente neutro, representa o dobro do valor observado na silagem de milho. Bueno et al. (2001), comparando a silagem de girassol com a silagem de milho observaram teor de fibra em detergente neutro na silagem de girassol inferior as outras silagens, e o teor de fibra em detergente ácido, superior à silagem de milho. Esses mesmos autores também mencionam que esse fato é devido ao maior teor de celulose e lignina e menor teor de hemicelulose da silagem de girassol, em relação à silagem de milho (Tabela 8). Comparando a silagem de girassol com as silagens de sorgo e milho por meio do consumo voluntário, digestibilidade aparente, balanço de nitrogênio e alguns parâmetros sangüíneos (Tabela 9), Almeida (1992) observou que a silagem de girassol não diferiu da silagem de milho no tocante ao consumo de matéria seca, energia bruta e energia digestível, mas foi superior à silagem de milho quanto ao consumo de proteína bruta e de proteína digestível. Com relação à silagem de sorgo, a silagem de girassol foi superior em todos os parâmetros de consumo avaliados. O maior consumo de proteína bruta e de proteína digestível observado para a silagem de girassol pode estar associado ao seu maior teor de proteína bruta, ou seja, 11,73; 7,97 e 8,65\% 
respectivamente, para silagens de girassol, sorgo e milho. No tocante à digestibilidade aparente, a silagem de girassol superou as silagens de sorgo e de milho quanto às digestibilidades da proteína bruta e da fibra em detergente ácido.

Tabela 8. Composição bromatológica de silagens de milho e girassol

\begin{tabular}{lcc}
\hline \multirow{2}{*}{ Parâmetro } & \multicolumn{2}{c}{ Silagem (\% MS) } \\
\cline { 2 - 3 } & Girassol & Milho \\
\hline Matéria seca & 21,98 & 34,62 \\
Proteína bruta & 11,61 & 9,40 \\
Fibra bruta & 26,12 & 24,99 \\
Extrato etéreo & 10,07 & 3,16 \\
Matéria orgânica & 85,36 & 94,19 \\
Matéria mineral & 14,64 & 5,81 \\
Extrato não-nitrogenado & 37,56 & 56,63 \\
Fibra em detergente neutro & 44,26 & 62,61 \\
Fibra em detergente ácido & 42,72 & 31,96 \\
Celulose & 31,99 & 27,05 \\
Hemicelulose & 1,53 & 30,29 \\
Lignica & 9,40 & 3,77 \\
\hline
\end{tabular}

Fonte: Bueno et al. (2001).

Ainda de acordo com Almeida (1992), os animais que receberam silagem de girassol tiveram maior quantidade de nitrogênio retido, o que pode ser função do maior consumo de proteína digestível, bem como da maior digestibilidade da proteína bruta observados para a silagem de girassol. $\mathrm{O}$ maior valor energético da silagem de girassol, ou seja, energia metabolizável de 2.548,19 kcal $/ \mathrm{kg}$, em relação às silagens de sorgo $(2.226,18 \mathrm{kcal} / \mathrm{kg})$ e de milho $(2.390,23 \mathrm{kcal} / \mathrm{kg})$, assim como o maior teor protéico da silagem de girassol, em relação às silagens de sorgo e de milho, são outras justificativas para a maior retenção de nitrogênio observada para a silagem de girassol, uma vez que a eficiência de utilização da proteína pode ser aumentada pelo suprimento de energia.

Ko et al. (2005) em estudo sobre consumo e digestibilidade da silagem de quatro genótipos de girassol (Rumbosol 91, M734, C11 e S430) em ovinos observaramn consumo voluntário de matéria seca de 63,60; 69,59; 50,18 e 74,53 $\mathrm{g} / \mathrm{kg} / \mathrm{dia}$, respectivamente e digestibilidade aparente da MS de 53,60; 53,29; 46,91 e 53,44\%, respectivamente. Os autores concluiram que as silagens podem ser classificadas como forrageiras de boa qualidade.
Tabela 9. Consumo, digestibilidade, balanço de nitrogênio e parâmetros sanguíneos em ovinos alimentados com silagens de girassol, sorgo e milho.

\begin{tabular}{|c|c|c|c|}
\hline & \multicolumn{3}{|c|}{ Silagem } \\
\hline & Girassol & Sorgo & Milho \\
\hline \multicolumn{4}{|c|}{ Consumo Voluntário (g/Kg/dia) } \\
\hline Matéria seca & $61,00^{\mathrm{a}}$ & $56,73^{\mathrm{b}}$ & $61,03^{\mathrm{a}}$ \\
\hline Proteína bruta & $7,07^{\mathrm{a}}$ & $4,76^{\mathrm{b}}$ & $5,08^{\mathrm{b}}$ \\
\hline $\begin{array}{l}\text { Proteína } \\
\text { digestível }\end{array}$ & $4,43^{\mathrm{a}}$ & $2,79^{\mathrm{b}}$ & $2,75^{\mathrm{b}}$ \\
\hline Energia bruta & $298,64^{\mathrm{a}}$ & $279,28^{\mathrm{b}}$ & $297,92^{\mathrm{a}}$ \\
\hline Energia digestível & 198,89 & $178,34^{\mathrm{b}}$ & $199,72^{\mathrm{a}}$ \\
\hline \multicolumn{4}{|c|}{ Digestibilidade aparente (\%) } \\
\hline Matéria seca & $63,11^{\mathrm{b}}$ & $63,53^{\mathrm{b}}$ & $65,88^{\mathrm{a}}$ \\
\hline Proteína bruta & $62,69^{\mathrm{a}}$ & $58,51^{\mathrm{b}}$ & $53,02^{\mathrm{c}}$ \\
\hline $\begin{array}{l}\text { Fibra em } \\
\text { detergente neutro }\end{array}$ & $61,98^{\mathrm{b}}$ & $67,68^{\mathrm{a}}$ & $66,95^{\mathrm{a}}$ \\
\hline $\begin{array}{l}\text { Fibra em } \\
\text { detergente ácido }\end{array}$ & $56,26^{\mathrm{a}}$ & $46,89^{\mathrm{b}}$ & $53,97^{\mathrm{b}}$ \\
\hline Energia bruta & $66,65^{\mathrm{ab}}$ & $65,90^{\mathrm{b}}$ & $67,43^{\mathrm{a}}$ \\
\hline \multicolumn{4}{|c|}{ Balanço de nitrogênio } \\
\hline & $4,82^{\mathrm{a}}$ & $3,04^{\mathrm{b}}$ & $3,46 \mathrm{~b}$ \\
\hline \multicolumn{4}{|c|}{ Parâmetros sanguíneos (mg/100ml) } \\
\hline Glicose & 57,49 & 57,62 & 57,57 \\
\hline Uréia & 21,66 & 18,15 & 19,43 \\
\hline
\end{tabular}

Médias com letras diferentes, na mesma linha, diferem entre si. Fonte: Adaptado de Almeida (1992).

\section{Grão de girassol}

A utilização de grãos de girassol na alimentação animal vem sendo bastante estudada. Isto se deve a alta qualidade de seu óleo, que atualmente é destinado principalmente à alimentação humana. O uso de grãos de girassol ou de seu óleo na alimentação de ruminantes se justifica, uma vez que os produtos oriundos de animais que ingeriram os mesmos apresentam alta qualidade. Qualidade essa conferida em razão do aumento na concentração nos produtos (leite ou carne) de ômega 6 e ácido linoléico conjugado, componentes estes extremamente benéficos a saúde humana. Além disso, no caso dos bovinos leiteiros, possibilita o aumento na produção de um alimento nobre, o leite, que é um dos alimentos mais consumidos no mundo (Gupta \& Das, 2000).

O grão de girassol apresenta uma matriz protéica (casca) rígida que envolve o grão, dessa forma, o fornecimento do grão inteiro pode prejudicar a utilização dos nutrientes pelos animais. Por outro lado, no caso dos ruminantes, o grão inteiro apresenta-se como uma forma de proteção contra a biohidrogenação dos ácidos 
graxos poli-insaturados pelas bactérias ruminais. Quando quebrado ou moído os nutrientes do grão podem ser rapidamente degradados no rúmen e os ácidos graxos poli-insaturados são mais facilmente biohidrogenados.

O grão de girassol destaca-se por suas características funcionais. A proteína desta semente oleaginosa apresenta propriedade que lhe confere grandes vantagens em sua utilização, como solubilidade, emulsificação, formação e estabilidade de espuma, formação de gel, absorção de água e de gordura (Damadaran, 1994). São bastante energéticos e protéicos, possuindo, em média, $40 \%$ de óleo de alto valor alimentício e $20 \%$ de proteínas (Tabela 10)

Tabela 10. Composição bromatológica, em $\%$ da matéria seca do grão de girassol

\begin{tabular}{lc}
\hline \multicolumn{1}{c}{ Itens } & Grão de girassol \\
\hline Matéria seca & 93,34 \\
Proteína bruta & 20,07 \\
Extrato etéreo & 48,42 \\
Fibra em detergente ácido & 16,73 \\
\hline
\end{tabular}

Fonte: Cobal (2011).

Em estudo realizado por Beran et al. (2007) para determinação da digestibilidadein situ de dietas contendo grão de girassol integral, torta de girassol, grão de soja integral e parcialmente desengordurado, farelo de soja, farelo de gérmen de milho desengordurado e concentrado comercial com $36 \%$ de $\mathrm{PB}$, foi constatado maiores digestibilidade total da MS e MO do grão integral de girassol, para todas as taxas de passagem, em relação a torta de girassol obtida com uma prensagem. Esses resultados indicam que o teor de óleo não teve efeito negativo na digestão destes componentes nutritivos. As digestibilidades observadas foram superiores aos 52,9 e $61,1 \%$ relatados por Bett et al. (2004) para a digestibilidade in vitro da MS de algumas variedades de grãos de girassol.

Gibb et al. (2004) avaliaram níveis de grão de girassol na dieta de terminação de 60 novilhos mestiços taurinos com peso inicial de aproximadamente $479 \mathrm{~kg}$. Os autores forneceram 9 e $14 \%$ de sementes de girassol ou 9 e $14 \%$ de sementes de girassol laminada na dieta controle em substituição a cevada. Não observaram alterações significativas no consumo de matéria seca e no ganho médio diário.

Bett et al. (2004), trabalhando com grão de girassol, observaram que ao quebrar o grão a degradabilidade efetiva a $5 \% / \mathrm{h}$ aumentou, demonstrando que a casca presente nesse ingrediente foi altamente resistente a degradação. Marchi (2010) ao avaliar o efeito da peletização do grão de girassol moído não observou efeito significativo da politização na digestão e desempenho dos animais, recomendando o seu fornecimento apenas moído.

Dados relatados por Anderson et al. (1984) citados por Bett et al. (2004) mostram que a incorporação de grão de girassol na dieta de vacas leiteiras proporcionou menor produção e menores teores dos componentes do leite, tais como proteína, gordura e sólidos, quando comparado a vacas recebendo dietas contendo caroço de algodão ou soja extrusada. As diferenças na digestibilidade das dietas e no peso corporal dos animais não foram significativas.

Homem Junior et al. (2010) não observaram diferença no ganho de peso e conversão alimentar de cordeiros Santa Inês mantidos em confinamento. Esse fato pode ser explicado pela maior concentração energética da dieta com grãos de girassol em relação à dieta controle, que, soma do ao consumo equivalente entre elas, resultou em melhores ganhos diários. Também vale ressaltar a redução da poeira decorrente da inclusão do grão do girassol, que propiciou boa aceitação pelos animais.

\section{Torta de girassol}

A torta de girassol é um dos coprodutos resultantes da extração mecânica do óleo da semente de girassol, possui pouco mais de $20 \%$ de proteína bruta e aproximadamente $15 \%$ de óleo, com base na matéria seca (Oliveira \& Lew, 2002; Sousa, 2008). O rendimento da torta de girassol varia de acordo com a variedade e o cultivar e, normalmente, com o processo de prensagem a frio, pode ser extraído em torno de $1 / 3$ de óleo em relação ao peso total dos grãos, e a torta poderá apresentar teores de extrato etéreo entre 10 e 27\% (Oliveira, 2003).

Assim como o farelo de girassol a torta tem sido estuda na alimentação de animais de produção como substituto do farelo de soja. Este ingrediente prevalece na composição dos concentrados, principalmente nas propriedades que trabalham com animais especializados em produção leiteira. Contudo, o aumento no custo de produção e a implementação de soja transgênica sem regulamentação clara, tornaram 
o farelo de soja uma fonte protéica onerosa e muito discutida. Além disso, o grande crescimento da população mundial e a exigência cada vez maior por alimentos de alto valor protéico, não competitivos com a alimentação humana, impulsionam a utilização de coprodutos na nutrição animal (Pinto \& Fontana, 2001).

A PB da torta de girassol caracteriza-se por ser extensamente degradável, sendo seu teor de proteína não degradável no rúmen menor que 10\% (Beran et al., 2007). Mupeta et al. (1997) observaram que a quantidade de aminoácidos não degradáveis no rúmen foi de $7,2 \%$ e a digestibilidade total aminoacídica foi elevada (95,6\%), já Goes et al. (2010), encontraram baixa e média degradabilidade ruminal da PB para a torta de girassol, pela técnica in situ, de $36,65 \%$ e $50,00 \%$, respectivamente. A variação entre estes valores pode ser devido ao processo de extração do óleo, ou a falta de uniformidade da torta em função da variedade utilizada, mostrando que se necessita de uma padronização para a torta de girassol.

Trabalhando com vacas da raça holandesa, no terço inicial de lactação, com produção de leite média de 17 kg/dia, Santos (2008) não observou diferença significativa $(\mathrm{P}>0,05)$ no consumo de matéria seca, em funções dos níveis parciais de substituição $(0,20,40$ e $60 \%)$ do farelo de soja e farelo de girassol pela torta de girassol. Todavia o consumo de matéria seca encontrado, 13,55 $\mathrm{kg} / \mathrm{vaca} /$ dia, esteve a baixo do predito para essa categoria, cerca de $15 \mathrm{~kg} / \mathrm{vaca} / \mathrm{dia}$, consequência dos baixos valores de DIVMS e DIVFDN nos concentrados e na silagem de milho.

O mesmo autor não observou diferença na produção de leite influenciada pelos tratamentos. Dos constituintes do leite, apenas a porcentagem de proteína e a concentração de $\mathrm{N}$-ureico, em $\mathrm{mg} / \mathrm{dL}$, apresentaram diferenças significativas $(\mathrm{P}<0,01)$. A porcentagem de proteína no leite diminuiu e a concentração de $\mathrm{N}$-uréico no leite aumentou linearmente, à medida que houve aumento da substituição do farelo pela torta de girassol.

Resultado semelhante foi observado por Santos et al. (2009), na avaliação de níveis crescentes da torta de girassol $(0,12,24,36 \%)$ na matéria seca do concentrado, em substituição a proteína do farelo de soja, não observaram diferenças no consumo de matéria seca, produção de leite, leite corrigido para 3,5\% de gordura, assim como as percentagens de gordura, proteína, lactose, sólidos totais e sólidos totais não gordurosos, mostrando ser uma fonte potencial na dieta de vacas leiteiras.

Stein (2003) trabalhou com substituição parcial do farelo de soja pela torta de girassol ( 0 , 25 e $50 \%$ na MS) em concentrados o que proporcionou a redução da digestibilidade da MS, para os níveis de substituição de 25 e $50 \%$. Já Silva (2004) fornecendo níveis crescentes de torta de girassol na dieta de vacas em lactação, encontrou $15 \%$ como sendo o limite máximo de inclusão deste alimento sem causar comprometimento no desempenho dos animais.

Alves et al. (2011) trabalhando com boregas em avaliação da subsituição do farelo de soja por torta de girassol observaram que a cada $1 \%$ de inclusão da torta de girassol à dieta reduziu o ganho médio diário $1,2 \mathrm{~g}$. Os autores atribuíram essa diminuição no desempenho dos animais pelo incremento dos níveis de extrato etéreo na dieta, com concomitante redução da produção de proteína microbiana, redução na disponibilidade de energia para síntese de proteína microbiana no rúmen e conseqüente limitação no suprimento de aminoácidos para a síntese de proteína muscular.

Avaliando níveis de substituição do farelo de soja por torta de girassol para novilhos cruzados Red Angus $x$ Nelore terminados em confinamento Garcia et al. (2011) não observaram diferença no desempenho dos animais, podendo a torta de girassol ser incluída em até $15 \%$ na dieta de bovinos em substituição ao farelo de soja, sem alterar o desempenho dos animais. Silva et al. (2011) também não obervaram diferença no desempenho na recria durante o período das águas para novilhos Nelore mantidos em pastagem de Brachiaria brizantha na substituição da proteína do farelo de soja pela proteína da torta de girassol em até $50 \%$.

Avaliando a degradabilidade in situ da torta de girassol, Goes et al. (2010) observaram que a fração potencialmente degradável da MS foi de $73,70 \%$ com fração solúvel de $22,91 \%$, que associado ao baixo tempo de colonização, proporcionou elevada degradabilidade efetiva para a MS (Tabela 2 e Figura 1) Em trabalho realizado por Lima (2011) foi observado que a substituição parcial em 30\% do farelo de soja por torta de girassol melhorou o ganho de peso diário e a condição corporal e a substituição de até $60 \%$ do farelo de soja pela torta de girassol não altera as características de carcaça de novilhas terminadas a pasto durante a época seca do ano. 
Pereira et al. (2011) trabalhando com níveis de inclusão de torta de girassol na ração concentrada $(0 ; 7 ; 14$ e 21\%), avaliaram a produção e composição e perfil de ácidos graxos do leite e não observaram diferença $(\mathrm{p}>0,05)$ entre os ácidos linoléico (C18:2n6c), araquídico (C18:3n6), linolênico (C18:3n3 ) e rumênico $(\mathrm{C} 18: 2 \mathrm{c} 9 \mathrm{t} 11)$ e observaram efeito linear decrescente com a adição dos níveis de torta de girassol para o ácido palmítico (C16:0).

$\mathrm{O}$ mesmo autor observou diferença na produção de leite média $(\mathrm{p}<0,05)$ com o aumento dos níveis de inclusão da torta de girassol. Observou também diminuição dos teores de proteína e gordura do leite linearmente, à medida que houve aumento da substituição do farelo pela torta de girassol.

Domingues et al. (2010) trabalhando com níveis de substituição de farelo de algodão por farelo de girassol $(0,25,50,75$ e 100\%) utilizando cinco animais fistulados no rúmen, machos, castrados, $1 / 2$ sangue Simental x Nelore, avaliaram os efeitos da torta de girassol sobre o consumo de matéria seca, $\mathrm{pH}$ e concentração de nitrogênio amoniacal no líquido ruminal e de uréia plasmática em novilhos de corte $\mathrm{e}$ concluíram que o consumo de matéria seca foi maior em animais alimentados com $0 \%$ de torta de girassol. No entanto, não foram observadas diferenças para os valores de $\mathrm{pH}$ e N-NH3 do líquido ruminal e uréia plasmática.

A adição da torta de girassol é mais estudada na dieta de ruminantes, todavia esse coproduto também pode ser utilizado na dieta de outros animais de interesse zootécnico. Costa et al. (2005) avaliando a inclusão de até $15 \%$ de torta de girassol na dieta de suinos em crescimento e terminação em subsituição ao farelo de soja, não observaram diferença no desempenho e qualidade da carcaça dos animais, sendo a inclusão de $15 \%$ com melhor índice de eficiência econômica.

O uso dos coprodutos do girassol é economicamente vantajoso em diversas situações tendo em vista que seu uso liberaria o farelo de soja para a exportação e consumo por outras espécies de interesse zootécnico (Ungaro, 2000).

\section{Farelo de girassol}

No Brasil, é imprescindível que sejam realizados trabalhos de pesquisa com o farelo de girassol, por ser este de menor custo em relação às outras fontes protéicas, para avaliar os efeitos de sua inclusão na alimentação animal como fonte protéica em substituição ao farelo de soja, com o intuito de aumentar a produção ou manter o nível de produção com redução dos custos de produção (Garcia et al., 2004).

Segundo Aguiar et al. (2003) no processo de obtenção do farelo de girassol são obtidos $45 \%$ de óleo, $25 \%$ de casca e $30 \%$ de farelo, com baixíssimo conteúdo de óleo, geralmente menos de $1 \%$ extrato etéreo na MS. Possui bom perfil de aminoácidos, contendo elevado teor de metionina, semelhante ao farelo de soja, porém limitante em lisina. Os valores de lisina variam entre 0,9 e $1,5 \%$, dependendo da presença maior ou menor de casca (Santos, 2008) (Tabela 11).

De acordo com Mendes et al. (2005) a maoir porcentagem de FDN no farelo de girassol quando comparado ao farelo de soja, fonte protéica usualmente utilizada nos concentrados, promove uma maior ingestão de fibra nas dietas, podendo limitar fisicamente o consumo dos animais pelo enximento do trato gastrointestinal. No trabalho realizado por Garcia et al. (2006), a substituição do farelo de soja por $45 \%$ de farelo de girassol não limitou o desempenho dos animais, por esse nível de substituição ter fornecido $41,3 \%$ de FDN na dieta.

Tabela 11. Composição do farelo de girassol obtido de sementes decorticadas e corticadas e farelo de soja.

\begin{tabular}{|c|c|c|c|}
\hline \multirow[b]{2}{*}{ Composição } & \multicolumn{2}{|c|}{ Farelo do grão de girassol } & \multirow[b]{2}{*}{$\begin{array}{c}\text { Farelo de } \\
\text { soja } \\
(\% \mathrm{MS})\end{array}$} \\
\hline & $\begin{array}{c}\text { Decorticada } \\
(\% \mathrm{MS})\end{array}$ & $\begin{array}{c}\text { Não } \\
\text { decorticada } \\
(\% \mathrm{MS})\end{array}$ & \\
\hline Matéria seca & 91,25 & 90,51 & 88,49 \\
\hline Proteína bruta & 32,62 & 37,50 & 48,69 \\
\hline Extrato Etéreo & 2,10 & - & 1,76 \\
\hline Fibra Bruta & 25,94 & 16,70 & 6,10 \\
\hline FDN & 43,56 & - & 15,54 \\
\hline FDA & 36,13 & - & 9,60 \\
\hline Lignina & 4,43 & - & 1,52 \\
\hline $\begin{array}{l}\text { Matéria } \\
\text { mineral }\end{array}$ & 5,38 & 6,90 & 6,39 \\
\hline Metionina & 0,69 & 0,62 & 0,61 \\
\hline Lisina & 1,22 & 1,02 & 2,81 \\
\hline
\end{tabular}

Fonte: Cqbal (2011).

Sharma et al. (2003) não observaram diferença, ao substituir 25 e $50 \%$ da proteína bruta de um concentrado protéico convencional pelo farelo de girassol não descorticado, na alimentação de vacas leiteiras. As digestibilidades da matéria orgânica, proteína bruta, extrato etéreo, fibra em detergente neutro e fibra em detergente ácido não apresentaram diferenças significativas. $\mathrm{O}$ consumo de matéria seca $(9,87 ; 9,78 ; 9,89 \mathrm{~kg} / \mathrm{d})$, produção de leite 
$(7,59 ; 7,99 ; 7,38 \mathrm{~kg} / \mathrm{dia})$ e teores de gordura $(4,19 ; 4,51 ; 4,73 \%)$ e proteína $(3,43 ; 3,58$; $3,78 \%$ ) do leite, para os tratamentos controle, $25 \%$ e $30 \%$ de substituição, respectivamente, foram semelhantes.

Garcia et al. (2004), avaliando a inclusão de 0 , 15,30 e $45 \%$ de farelo de girassol em concentrados para bovinos leiteiros, em fase de crescimento, não encontraram efeito dos níveis de inclusão sobre os coeficientes de digestibilidade aparente da MS (82,3\%), PB $(82,2 \%), \mathrm{EE}(57,2 \%)$, ENN $(92,6), \mathrm{FB}(44,8 \%)$, FDN $(72,5 \%)$ e FDA $(70,5 \%)$. Concluindo que, até o nível $45 \%$ de inclusão no concentrado, o farelo de girassol pode ser utilizado, com eficiência, na dieta de bovinos leiteiros em fase de crescimento.

Garcia et al. (2006) avaliando níveis crescentes de inclusão do farelo de girassol $(0$, 15,30 e $45 \%$ ) em substituição ao farelo de soja no concentrado para bovinos leiteiros em crescimento, mantidos em sistema de confinamento recebendo silagem de milho como volumoso e relação volumoso:concentrado de 57:43, não observaram diferença significativa para o ganho de peso diário dos animais. O nível de substituição de $45 \%$ proporcionou um ganho de peso de 156 gramas por dia a mais em relação ao nível de substituição $0 \%$, representando um ganho de $14 \mathrm{~kg}$ em confinamento de 90 dias. Malhado et al. (2011) não obervaram efeito significativo da substituição do farelo de soja por farelo de girassol para novilhos Nelore mantidos em pastagem de Brachiaria brizantha no período de secas. Contudo, animais suplementados com $0 \%$ farelo de girassol apresentaram maior ganho médio diário $(0,650 \mathrm{~kg})$ em comparação aos bovinos suplementados com 50\% farelo de girassol, $100 \%$ farelo de girassol e sal que obtiveram ganho médio diário de $0,558 \mathrm{~kg} ; 0,521$ $\mathrm{kg}$ e $0,161 \mathrm{~kg}$, respectivamente. O nível de substituição de $0 \%$ apresentou um ganho de $11,61 \mathrm{~kg}$ em relacao ao nível $100 \%$. Em ambas situações deve-se avaliar a viabilidade econômica dessa substituição, verificando o preço de compra do farelo de girassol na região e a possibilidade de manter os animais por um período superior recebendo essas dietas compostas pelo farelo de girassol em substituição ao farelo de soja.

Em trabalho realizado por Louvandini et al. (2007) com níveis de substituição do farelo de soja por farelo de girasol $(0,50$ e $100 \%)$ no concentrado para ovinos Santa Inês em terminação, observaram desempenho inferior e características de carcaça inferiores para os animais que receberam farelo de girassol na dieta.

O estudo da substituição do farelo de soja pelo farelo de girassol não se limita somente a avaliação dos seus efeitos na dieta de ruminantes. Assim, Silva et al. (2002) não verificaram efeito da substituição parcial do milho e farelo de soja pelo farelo de girassol na dieta de suínos nas fases de crescimento I ( $20 \mathrm{a} 50 \mathrm{~kg}$ de peso vivo), crescimento II ( entre 50 a $80 \mathrm{~kg}$ de peso vivo) e terminação (80 a $120 \mathrm{~kg}$ de peso vivo). Os autores concluem que a inclusão de até $21 \%$ de farelo de girassol nas dietas de leitões em crescimento e terminação, não influenciou as características de desempenho e de carcaça.

Furlan et al. (2001a) trabalhando com níveis de substituição da proteína do farelo de soja pela proteína do farelo de girassol $(10,20,30,40$ e $50 \%$ ) utilizando 1200 pintos de um dia de idade concluíram que em rações isoenergéticas e isoaminoacídicas para metionina+cistina e lisina digestíveis, a proteína do farelo de soja pode ser substituída pela proteína do farelo de girassol até o nível de 30\%, o que corresponde a cerca de $15 \%$ de inclusão de farelo de girassol nas rações dos frangos de corte.

Em outro trabalho, Furlan et al. (2001b) avaliaram o ensaio de desempenho utilizando cinco níveis de substituição $(0,25,50,75$ e $100 \%$ da proteína bruta do farelo de soja pela proteína do farelo de girassol para coelhos da raça Nova Zelândia em crescimento. Não foram

observadas diferenças significativas $(\mathrm{P}>0,05)$ para qualquer característica avaliada em nenhum dos níveis de inclusão, indicando a possibilidade de substituição do farelo de soja por farelo de girassol nas rações de coelhos em crescimento.

\section{Conclusão}

O uso dos subprodutos do Biodiesel na alimentação dos animais de interesse zootécnico, principalmente os oriundos da cultura do girassol, como o farelo e a torta, é de grande interesse, possibilitando a diminuição do passivo ambiental e reduzindo os custos de produção. Foi demonstrado através de vários trabalhos que a substituição do farelo de soja, principal fonte protéica utilizada na nutrição animal, pelo farelo e torta de girassol, mantém o nível de produção e reduz seus custos. Todavia, é preciso avaliar o custo de aquisição destes subprodutos na região, 
verificando a viabilidade econômica dessa substituição. É possível a utilização de miniprensas por pequenos produtores para extração do óleo das sementes de girassol na propriedade e sua comercialização e uso da torta para alimentação dos animais. $\mathrm{O}$ girassol apresenta capacidade a diversas condições edafoclimáticas, é resistente a secas e possui capacidade de extração de nutrientes das camadas mais profundas do solo, melhorando a produtividade das culturas sucessiva.

\section{Referências Bibliográficas}

Aguiar, R.H., Benedetti, B.C., Gonçalves, L.A.G. 2003. Óleo de Girassol (Heliantus annus L.) extraído a frio. In: Simpósio Internacional: Tendências e Inovaçãoes em Tecnologia de óleos e Gorduras, 2003, Campinas Anais... Campinas: Unicamp.

Almeida, M.F. 1992. Composição química, digestibilidade e consumo voluntário das silagens de sorgo (Sorghum vulgare L.) em dois momentos de corte, girassol (Helianthus annuus L.) e milho (Zea mays L.) para ruminantes. Lavras, MG, 1992, 100p. Dissertação (Mestrado em Zootecnia) Universidade Federal de Viçosa.

Alves, A.O., Paula, G.G.G., Alves, L.A.C., Fracarolli, J.P., Carsoso, K.G.M., Dorneles, A., Cabral, L.S. \& Zervoudakis, J.T. 2011. Desempenho de ovinos em confinamento submetidos a dietas com níveis crescentes de torta de girassol. In: Congresso Brasileiro de Zootecnia, 21, 2011, Maceió, Alagoas. Anais... Maceió: ABZ.

Beran, F.H.B., Silva, L.D.F., Ribeiro, E.L.A., Rocha, M.A., Ezequiel, J.M.B., Correa, R.A., Castro, V.S. \& Silva, K.C.F. 2007. Avaliação da digestibilidade de nutrientes, em bovinos, de alguns alimentos concentrados pela técnica de três estádios. Revista Brasileira de Zootecnia, 36, 130-137.

Bueno, M.S., Ferrari Junior, E., Leinz, F.F. 2001. Silagens de milho e girassol com diferentes proporções da ração concentrada na dieta de ovinos. In: Reunião Anual da Sociedade Brasileira de Zootecnia, 38, 2001, Piracicaba. Anais... Piracicaba: SBZ, 1296-1297.

Carvalho, M.A. Girassol: proposta de preço mínimo safra 2006/2007. Disponível:<www.conab.gov.br/conabweb/do wnload/precos_minimos/proposta_de_precos_ minimos_safra_2006_07_girassol.pdf> Acesso em: 27/05/2011.

CONAB. Conjuntura mensal: 2014. Disponível em: <http://www.conab.gov.br>. Acesso em: 28/07/2014.

Composição Química e Bromatológica Dos Alimentos (Cqbal 3.0) Disponível em: <http://cqbal.agropecuaria.ws/webcqbal/apres entacao.php>, Acesso em: 20/06/2011.

Correia, I.M.S. Extração e pirólise do óleo de girassol (Helianthus annus L.) visando a producao de biocombustíveis. Natal, RN, 2009, 105 pag. Dissertaçao (Mestrado em Engenharia Química) - Universidade Federal do Rio Grande do Norte., 2009.

Costa, M.C.R., Silva, C.A., Pinheiro, J.W., Fonseca, N.A.N., Souza, N.E., Visentainer, J.V., Belé, J.C., Borosky, J.C., Mourinho, F.L. \& Agostini, P.S. 2005. Utilização da torta de girassol na alimentação de suínos nas fases de crescimento e terminação: efeitos no desempenho e nas características de carcaça. Revista Brasileira de Zootecnia, 34, 15811588.

Domingues, A.R., Silva, L.D.F., Ribeiro, E.L. A., Castro, V.S., Barbosa, M.A.A.F., Mori, R.M., Vieira, M.T.L. \& Silva, J.A.O. 2010. Consumo, parâmetros ruminais e concentração de uréia plasmática em novilhos alimentados com diferentes níveis de torta de girassol em substituição ao farelo de algodão. Semina: Ciências Agrárias, 31, 1059-1070.

Evangelista, A.R. \& Lima, J.A. 2001. Utilização de silagem de girassol na alimentação animal. In: Simpósio Sobre Produção e Utilização de Forragens Conservadas, 2001, Maringá, PR. Anais... Maringá: UEM/CCA/DZO.

Fernandes, A.R.M., Sampaio, A.A.M., Henrique, W., Oliveira, E.A., Tullio, R.R. \& Oliviera, R. V. 2007. Avaliação bioeconômica da terminação de bovinos Canchim, machos e fêmeas, em confinamento. In: Reunião Anual da Sociedade Brasileira de Zootecnia, 43, 2007, Jaboticabal, SP. Anais... Jaboticabal: SBZ.

Furlan, A.C., Mantovani, C., Murakami, A.E., Moreira, I. Scapinello, C. \& Martins, E.N. 2001a. Utilização do Farelo de Girassol na Alimentação de Frangos de Corte. Revista Brasileira de Zootecnia, 30, 158-164. 
Furlan, A.C., Faria, H.G., Scapinello, C., Moreira, I., Murakami, A.E. \& Santolin, M.L.R. 2001b. Farelo de girassol para coelhos em crescimento: digestibilidade e desempenho. Revista Brasileira de Zootecnia, 30, 158-164.

Garcia, J.A.S., Vieira, P.F., Cecon, P.R., Setti, M.C., Mcmanus, C. \& Louvandini, H. 2006. Desempenho de bovinos leiteiros em fase de crescimento alimentados com farelo de girassol. Ciência Animal Brasileira, 7, 223233.

Garcia, J.A.S; Vieira, P.F., Cecon, P.R; Melo, G.M.P., Martins, A.S \& Setti, M.C. 2004. Digestibilidade aparente do farelo de girassol na alimentação de bovinos leiteiros em fase de crescimento. Ciência Animal Brasileira, 5, 123-129.

Garcia, J., Mexia, A.A., Coelho, R.N., Alcalde, C.R., Reis, T.A., Luna, U.V., Geron, L.J.V. 2011. Desempenho de novilhos terminados em confinamento alimentados com níveis de torta de girassol na dieta. In: Congresso Brasileiro De Zootecnia, 21, 2011, Maceió, Alagoas. Anais... Maceió:ABZ.

Gibb, D.J., Owens, F.N., Mir, P.S. \& Mcallister, T.A. 2004. Value of sunflower seed in finishing diets of feedlot cattle. Jounal of Animal Science, 82, 2679-2692.

Goes, R.H.T.B., Souza, K.A., Patussi, R.A., Cornelio, T.C., Oliveira, E.R. \& Brabes, K.C.S. 2010. Degradabilidade in situ dos grãos de crambe, girassol e soja, e de seus coprodutos em ovinos. Acta Scientiarum. Animal Sciences, 32, 271-277.

Gupta, R.K. \& Das, S.K. 2000. Fracture resistance of sunflower seed and kernel to compressive loading. Journal of Food Engineering, 46, 1-8

Homem Junior, A. C., Ezequiel, J.M.B., Galati, R.L., Gonçalves, J.S., Santos, V.C. \& Sato, R.A. 2010. Grãos de girassol ou gordura protegida em dietas com alto concentrado e ganho compensatório de cordeiros em confinamento. Revista Brasileira de Zootecnia, 39, 563-571.

Jayme, D.G. Avaliação nutricional de silagens de quatro genótipos de girassol (Helianthus annuus). Belo Horizonte, MG, 2003, 78p. Tese (Doutorado em Zootecnia) Universidade Federal de Minas Gerais, 2003.
Ko, H.J.F., Reis, R.B., Gonçalves, L.C., Rodrigues, J.A.S., Rodriguez, N.M. \& Sousa, B.M. 2005. Consumo voluntário e digestibilidade aparente da matéria seca, matéria orgânica, energia e parede celular das silagens de quatro genótipos de girassol (Helianthus annus). Arquivo Brasileiro de Medicina Veterinária e Zootecnia, 57, 616622.

Leite, L.A., Silva, B.O., Reis, R.B., Faria, B.N., Gonçalves, L.C., Coelho, S.G. \& Saturnino, H.M. 2006. Silagens de girassol e de milho em dietas de vacas leiteiras: consumo e digestibilidade aparente. Arquivo Brasileiro de Medicina Veterinária e Zootecnia, 58, 1192-1198.

Lima, H.L. 2011. Parâmetros nutricionais em novilhos suplementados com torta de girassol em pastejo de Brachiaria brizantha cv. Marandu. Dourados, MS, 2011, 64p. Dissertação (Mestrado em Zootecnia) Universidade Federal da Grande Dourados.

Louvandini, H., Nunes, G.A., Garcia, J.A.S., Mcmanus, C., Costa, D.M. \& Araújo, S.C. 2007. Desempenho, características de carcaça e constituintes corporais de ovinos Santa Inês alimentados com farelo de girassol em substituição ao farelo de soja na dieta. Revista Brasileira de Zootecnia. 36, 603-609.

Malhado, A.L.N., Mesacasa, A.C., Zervoudakis, J.T., Hatamoto-Zervoudakis, L.K., Cabral, L.S., Silva, R.G. F., Silva, R.P. \& Alonso, M.K. 2011. Suplementação de bovinos em pastejo com farelo de girassol durante o período das secas: Desempenho produtivo. In: Congresso Brasileiro De Zootecnia, 21, 2011, Maceió, Alagoas. Anais... Maceió: ABZ.

Massaro Júnior, F.L., Bett, V., Mori, R.M., Domingues, A.R., Castro, V.S., Silva, C.R.B. \& Silva, L.D.F. 2006. Substituição de farelo de algodão por torta de girassol nas dietas de bovinos de corte: degradabilidade e digestibilidade. In: XV Encontro Anual de Iniciação Científica, 2006, Ponta Grossa, PR. Anais... Ponta Grossa: UEPG.

Mendes, A.R., Ezequiel, J.M.B., Galati, R.L., Feitosa, J.V. 2005. Desempenho, parâmetros plasmáticos e características de carcaça de novilhos alimentados com farelo de girassol e diferentes fontes energéticas, em confinamento. Revista Brasileira de Zootecnia, 34, 692-702. 
Mizubuti, I.Y., Ribeiro, E.L.A., Rocha, M.A., Silva, L.D.F., Pinto, A.P., Fernandes, W.C. \& Rolim, M.A. 2002. Consumo e digestibilidade aparente das silagens de milho (Zea mays L.), sorgo (Sorghum bicolor (L.) Moench) e girassol (Helianthus annuus L.). Revista Brasileira de Zootecnia, 31, 267-272.

Mupeta, B., Weisbjerg, M.R., Hvelplund, T. \& Madsen, C,J. 1997. Digetibility of amino acids in protein rich tropical feeds for ruminants estimated with the mobile bags technique. Animal Feed Science Tecnology, 69, 271-80.

Nogueira Junior, S. 2006. Programa biodiesel: agora é para valer? Análise e Confinamento. Revista indicadores do agronegócio. Informações Econômicas, São Paulo, 1, 10

Oliveira, A.S. 2008. Coprodutos da extração de óleo de sementes de mamona e de girassol na alimentação de ruminantes. Viçosa, MG, 2008, 166p. Tese (Doutorado em Zootecnia) Universidade Federal de Viçosa.

Oliveira, A.S., Pina, D.S., Campos, J.M.S. 2010. Coprodutos do Biodisel na alimentação de ruminantes. In: Simpósio sobre manejo estratégico da pastagem, 5, 2010, Viçosa, MG. Anais... Viçosa, p.420-461.

Oliveira, M.D.S. 2003. Torta da prensagem a frio na alimentação de bovinos. In: Simpósio Nacional, 3 Reunião Nacional da Cultura do Girassol, 14, 2003., Ribeirão Preto. Anais... Ribeirão Preto, Palestras.

Oliveira, M.F., Vieira, O.V. 2004. Extração de óleo de girassol utilizando miniprensa. Embrapa Soja, Londrina, Documentos 237.

Pereira, L.G., Gonçalves, L.C., Rodrigues, J.A.S. \& Borges, I. 1999. Avaliação de diferentes épocas de ensilagem da cultura do girassol (Helianthus annuus L.). III. Densidade, matéria seca e proteína bruta das silagens. Embrapa Soja, Londrina, Documentos 135.

Pereira, E.S., Pimentel, P.G., Bomfim, M.A.D., Carneiro, M.S. De S., Cândido, M.J.D. 2011 Torta de girassol em rações de vacas em lactação: produção microbiana, produção, composição e perfil de ácidos graxos do leite. Acta Scientiarum. Animal Sciences. 33, 387394.

Pinto, J.H.E. \& Fontana, A. 2001. Canola e Girassol na alimentação animal. In: Simpósio Sobre Ingredientes Na Alimentação Animal,
2001, Campinas, SP. Anais... Campinas, p.109-134,

Rezende, A.V., Evangelsita, A.R., Siqueira, G.R. Vilela, H.H. \& Lopes, J. 2007. Valor nutritivo de silagens de seis cultivares de girassol em diferentes idades de corte. Ciência $e$ Agrotecnologia, 31, 896-902.

Resende, A.V. \& Evangelista, A.R. 2009. Avaliação do potencial do girassol (Helianthus annuus) como planta forrageira para silagem e para associar-se ao capimElefante (Pennisetum purpureum schum.) na ensilagem. In: Congresso Brasileiro de Plantas Oleaginosas, Óleos Vegetais e Biodiesel, 1, 2004, Varginha, MG. Anais... Varginha: UFLA.

Ribeiro, E.L.A., Rocha, M.A., Mizubuti, I.Y. \& Silva, L.D.F. 2002. Silagens De Girassol (Helianthus annuus L.), milho (Zea mays L.) e sorgo (Sorghum bicolor (L.) Moench) para ovelhas em confinamento. Ciência Rural, 32, 299-302.

Santos, A.X., Oliveira, A.A., Massaro Junior, F.L., Lançanoca, J.A. C; Silva, L.D.F., Pecoraro, C. \& Leme, M.C.J. 2009. Torta de girassol na dieta de vacas em lactação. In: Reunião Anual da Sociedade Brasileira de Zootecnia, 46, 2009, Maringá, PR. Anais... Maringá: SBZ.

Santos, J. 2008. Derivados da extração do óleo de girassol para vacas leiteiras. Jaboticabal, SP, 2008, 95p. Tese (Doutorado em Zootecnia) Universidade Estadual Paulista "Júlio de Mesquita Filho".

Silva, C.A., Pinheiro, J.W., Fonseca, N.A.N., Cabrera, L., Novo, V.C.C., Silva, M.A.A., Canteri, RC. \& Hoshi, E.H. 2002. Farelo de girassol na alimentação de suínos em crescimento e terminação: digestibilidade, desempenho e efeitos na qualidade de carcaça. Revista Brasileira de Zootecnia, 31, 982-990.

Silva, Z. F. 2004. Torta de Girassol na alimentação de vacas em lactação. Jaboticabal, SP, 36p. Dissertação (Mestrado em Zootecnia), Universidade Estadual Paulista "Júlio de Mesquita Filho".

Silva, R.G.F., Zevoudakis, J.T., Sousa, D.P., Hatamoto-Zervoudakis, L.K., Costa Filho, M.F., Silva, R.P., Tsuneda, P.P. \& Luna, B.M. 2011. Desempenho produtivo de novilhos em pastejo suplementados com torta de girassol 
no período das águas. In: Congresso Brasileiro de Zootecnia, 21, 2011, Maceió, Alagoas. Anais... Maceió:ABZ.

Sharma, K., Dutta, N., Pattanaik, A.K. \& Hasan, Q.Z. 2003. Replacement value of undecorticated sunflower meal as a supplement for milk production by crossbred cows and buffaloes in the Northern Plains of India. Tropical Animal Health and Production, 35, 131-145.

Sindirações. Setor de Alimentação Animal. Boletim Informativo do Setor, 2011. Disponível em: <http://www.sindiracoes.org.br/images/stories /noticias/boletim\%20mar\%E7o\%20\%202011 \%20final.pdf> acesso em: 19/05/2011.

Singh, J. \& Bargale, P.C. 2000. Development of a small capacity double stage compression screw press for oil expression. Journal of Food Engineering, 43, 75-82.

Sousa, C.C. 2008. Avaliação econômica parcial de dietas com o farelo e a torta de girassol, na alimentação de vacas leiteiras. Jaboticabal,
SP, 2008, 33p. Dissertação (Mestrado em Zootecnia) - Universidade Estadual Paulista "Júlio de Mesquita Filho".

Stein, M.S. 2003. Digestibilidade in vitro de concentrados com diferentes níveis de torta de girassol, 2003, 43f. Monografia (Graduação em Zootecnia) - Faculdade de Ciências Agrárias e Veterinárias. Universidade Estadual Paulista, Jaboticabal - SP.

Ungaro, M.R.G. 2000. Cultura do girassol. Campinas: Instituto Agronômico de São Paulo, (Boletim Técnico, 188).

Recebido em Agosto 8, 2014

Aceito em Outubro 7, 2014

License information: This is an open-access article distributed under the terms of the Creative Commons Attribution License, which permits unrestricted use, distribution, and reproduction in any medium, provided the original work is properly cited. 